\title{
From Poland to France with Amo(u)r: Elena Poniatowska's Mexican Crónicas
}

Depuis la Pologne vers la France avec amo(u)r: les Chroniques mexicaines d'Elena Poniatowska's

John S. Bak and Aleksandra Wiktorowska

\section{CpenEdition}

\section{Journals}

Electronic version

URL: https://journals.openedition.org/recherchestravaux/3614

DOI: 10.4000/recherchestravaux.3614

ISSN: 1969-6434

\section{Publisher}

UGA Éditions/Université Grenoble Alpes

Printed version

ISBN: 978-2-37747-301-4

ISSN: 0151-1874

\section{Electronic reference}

John S. Bak and Aleksandra Wiktorowska, "From Poland to France with Amo(u)r: Elena Poniatowska's Mexican Crónicas", Recherches \& Travaux [Online], 98 | 2021, Online since 28 June 2021, connection on 09 August 2021. URL: http://journals.openedition.org/recherchestravaux/3614 ; DOI: https://doi.org/ 10.4000/recherchestravaux.3614

This text was automatically generated on 9 August 2021.

(c) Recherches \& Travaux 


\title{
From Poland to France with Amo(u)r: Elena Poniatowska's Mexican Crónicas
}

\author{
Depuis la Pologne vers la France avec amo(u)r : les Chroniques mexicaines \\ d'Elena Poniatowska's
}

John S. Bak and Aleksandra Wiktorowska

\section{Introduction}

1 If journalism is the first draft of history, as the Washington Post's Phil Graham once quipped, then literary journalism is history's second, third or even fourth draft. Some would even say that literary journalism, given its scrupulous attention to detail and fact, is history recorded in situ. And while literary journalism's past dates back to Europe's 19th-century chronique and early 20 th-century reportage, its present is undoubtedly centralized in the Americas, from the cronistas south of the 28th parallel to the New Journalists north of the line. One literary journalist who combined these two American traditions, and who still managed to keep one foot in Europe, is the Parisian born Mexican cronista of royal Polish blood, Elena Poniatowska Amor. Her nonfiction over the past half-century or more has focused on Mexico's struggle with democracy, poverty and corruption; but it has also championed a universal plea for social justice and gender equality that has equally resounded across the Gulf and the Atlantic.

2 A native French speaker at the time she and her mother fled Paris in 1941 at the age of nine, Poniatowska later adopted English as her second language while studying at a Catholic school in the United States. Her new American identity, however, was rather short-lived. In returning not long after to her mother's native Mexico, Poniatowska had effectively cut ties with Europe and the United States, making the country her home and Spanish, a language she had learned from her family's servants, her lingua franca. And yet, with a Mexican mother and a Polish father who were both "in many important ways French" and who "only [spoke] French and English [...] at home", Poniatowska 
could not entirely deny her aristocratic "social roots" or her conservative "political antecedents". ${ }^{1}$

3 Her knowledge of French, in fact, helped her to capture the zeitgeist of postwar France, putting her journalistic skills to use in collecting oral histories and interviewing the nation's luminaries in her Jardín de Francia (2008), a collection of 109 crónicas written between 1953 and the 1980s. Several of these interviews were recorded during the 1950s with dozens of French authors, artists and political dignitaries, including Jean Cocteau, Jean Vilar, Abbé Pierre, Françoise Sagan, and Jean-Paul Sartre. They provide a rare glimpse into the French mindset from a young exile. Isabelle Tauzin-Castellanos calls the book her a "[b]ouquet of chronicles and interviews of figures of French culture in Mexico City or in Paris". ${ }^{2}$ But these interviews, not unlike those of Studs Terkle in Working (1974) or Truman Capote in Music for Chameleons (1980), also say a lot about the author asking the questions. In her infamous interview with recent Nobel laureate François Mauriac, for instance, she arrived without having even bothered to read any of his books, and ended up asking him if his "throat hurt". Although he insisted that "no conversation was possible" 3 between them, she somehow still managed to get him to talk about his political ideologies. Her tiny frame, ingénue appearance and feigned insouciance often disarmed her more reserved, august subjects, and they consequently let down their guard and opened up to her.

4 Poniatowska could easily mingle with Europe's intelligentsia, but she preferred walking among Mexico's poor and working class. Trained as a journalist at a time when few women in Mexico held that position, the young blue-blood was, as Beth E. Jörgensen describes Poniatowska, a champion of the oppressed and an "advocate of women's voices and histories"4. We see this clearly in her early work, Palabras cruzadas. Crónicas (1961), where a collection of interview-articles with celebrated artists and painters in Mexico broaches more sensitive topics about the nation's poverty stricken than it does the artists' works. Her later chronicles would only further her sociopolitical commitment. La noche de Tlatelolco. Testimonios de la historia oral (published in Mexico in 1971 and translated into English in 1975 as Massacre in Mexico and into French in 2014 as La Nuit de Tlatelolco) reconstructs, in a hybrid text of personal interviews, political statements, graffiti, government documents and newspaper clippings, the massacre that ended a nine-week student demonstration in 1968, just ten days before Mexico City was to host the Olympics Games. Fuerte es el silencio (1980), which many feel, including Poniatowska herself, is the follow-up to La noche de Tlatelolco, is a crónica that stitches together five stories that capture the heart and soul of Mexican history, revisiting the student strikes of 1968 but also calling out the growing list of Mexico's despaparecidos, those kidnapped by the nation's police, military, and drug cartels. Nada, nadie. Las voces del temblor, published in Mexico in 1986 and translated into English in 1995 as Nothing, Nobody: The Voices of the Mexico City Earthquake, narrates the events that took place on 19 September 1985 when a powerful earthquake hit Mexico City in the early morning hours. The post-disaster testimonies speak of the death of family members and of entire neighborhoods, of the destruction of homes and hospitals-the collective loss of a city that left blood on the hands of a corrupt government which was slow in responding to the emergency relief efforts and which had grafted out contracts to companies whose shoddy buildings could not resist the shockwaves. And there is also Amanecer en el Zócalo. Los 50 días que confrontaron a México (2007), a crónica about the controversial events of the 2006 Mexican Presidential election, in which the former 
Mayor of Mexico City, Andrés Manuel López Obrador, the election front runner, mysteriously lost by less than one percent.

5 Poniatowska is, without question, one of the world's leading literary journalists and champions of the oppressed. And yet, strangely enough, her literary journalism has attracted little attention in France and Poland, passing under the radar of nearly all reading publics, save a few media scholars or translators, such as Françoise Léziart, Rachel Bisson-Fradet, Isabelle Tauzin-Castellanos, and Marie Cordoba in France, and Beata Babad, Carlos Marrodán Casas, and Łukasz Czarnecki in Poland. In countries where le journalisme littéraire and reportaż have enjoyed long and rich traditions and, today, are even thriving in their respective print cultures, why has this Polish FrancoMexican literary journalist been so neglected in both her birth and blood countries? The reasons differ in degree, but translations efforts in both countries suggest that the French and the Poles find Poniatowska to be more a novelist interested in women's biographical fiction and less a literary journalist who has brandished her pen repeatedly to defend the marginalized and to expose the corrupt.

6 By examining the international literary journalistic and reportage traditions inscribed within Elena Poniatowska's most celebrated crónica, La noche de Tlatelolco, a tradition that frees the work from its Mexican roots and elevates it among the world's best reportage books, this article attempts to counter these current trends in France and in Poland that see Poniatowska strictly as a Latin American Boom writer and, as such, favor her fiction over her socially-engaged literary journalism. A daughter of France with royal Polish blood (particularly dear to the Lorraine region), Poniatowska might have focused her attention this past half century on the troubled history of her adopted nation and on its victimized and marginalized peoples, but her journalistic themes, oral histories, interviewing techniques and literary talents are as universal as those from any French or Polish grand reporter, be it Jean Hatzfeld or Ryszard Kapuściński. Learning more about the plight of Mexico in particular, and of the Latin American crónica in general would be furthering Europe's engagement with the socio-political goals of literary journalism around the world, with Elena Poniatowska as our guide.

\section{La noche de Tlatelolco as Mexican crónica and European reportage}

7 Argentinian literary journalist Roberto Herrscher writes of Poniatowska: "Outside the Spanish-speaking world, the knowledge of her output is limited. Some of her novels, like Leonora and Tinísima, have achieved some success in English, French, and Italian. But her literary journalism has been largely restricted to the academic world." ${ }^{5}$ This shortcoming could soon be corrected, given the fact she was awarded the Premio Cervantes in 2013 (the Spanish "Nobel" prize for hispanophone literature), and Svetlana Alexievich-a literary journalist whose books draw on similar oral history testimonials-won the Nobel Prize in Literature in 2015 for "her polyphonic writings, a monument to suffering and courage in our time". The Nobel committee could just as well have been describing the half-century plus career of Poniatowska, as Sara Poot Herrera notes: "Throughout her career, her writing alternately appears as the interview, the chronicle and fiction-novel, short story-the essay, the art critique, the hybrid book, pure science, the art of arts that Poniatowska intersects with literature." 
8 A first reason for Poniatowska's neglect in France and Poland is probably linked to the fact that, in developing her brand of literary journalism, she was seemingly inspired more by the Americas than by her native Europe. Even if her social education was instituted in Paris, her formal education began in the US, and her professional training took shape in Mexico when she began writing short chronicles for the daily Excélsior in 1953, earning 15 pesos (about \$1) per story, before moving on to Novedades two years later. ${ }^{7}$ As her news stories developed, so too did her voice. As Françoise Léziart writes, Poniatowska "drew much of her inspiration from the movement born in the United States in the 1950s known as the 'New Journalism' whose aim was to raise journalism to the level of literature through the use of narrative techniques that would transpose the common into the universal". ${ }^{8}$ Dolly and William Young even go so far as to argue that La noche de Tlatelolco, arguably her greatest literary journalistic work, was directly inspired by the New Journalism:

Individual testimonies are interspersed throughout the book in such a way that the reader becomes acquainted with the witnesses to the massacre as one would the characters of a novel. Poniatowska is able to recreate the lenguaje popular so skillfully that her text weaves a colorful tapestry of Tlatelolco 1969 [sic] revealing much more than any mere chronicle of events. ${ }^{9}$

However, given Poniatowska's leftist sympathies for the neglected or forgotten Other in Mexico, hispanophone media historian Viviane Mahieux argues that she never entirely abandoned her French chronique or reportage heritage:

That both Poniatowska and Lispector, like Storni before them, were born in Europe and emigrated to Latin America as children might also have played a role in their dedication to the chronicle. They needed to establish themselves as cultural insiders, and the chronicle provided them with the ideal means to do so. ${ }^{10}$

10 This is not to imply that American literary journalism was not inherently leftist, which it was in the decades following World War I. But a leftist American reportage literature, such as we find in magazines like The New Masses or The Anvil during the 1930s or 40s, was rather short-lived, owning to the ideological loggerheads the United States soon found itself engaged in with pro-Marxist Russia after World War II:

In what proved to be one of its most significant, though by no means first, transnational mutations, literary journalism temporarily fused with literary reportage. But a second world war soon divided the world, and American plutocracy denuded literary reportage of its Marxist agenda. Literary journalism would continue to fight against objective reality, but now without the political ideologies of its European sibling [...]. ${ }^{11}$

11 The post-war New Journalists were not entirely apolitical, but they were cultural insiders, an elite journalistic corps writing more often about New York's privileged societies than its dark underbelly, and Poniatowska was not one to celebrate her own "absurd nobility": "Given Poniatowska's strong left-wing inclinations, [...] some people in Europe have dubbed her 'La Princesse Rouge". ${ }^{12}$ As Léziart explains, " The Mexican journalist had, in fact, functioned as an intermediary between an enlightened middle class and the lower strata of society". ${ }^{13}$ She represents, then, the perfect amalgam of the world's leading three literary journalistic traditions: Latin American, European and American.

Debates, then, about the percentage of America's New Journalism and Europe's reportage in Poniatowska's journalistic DNA are moot once we accept that her nonfiction is undeniably tied to two genres uniquely Latin American in their objective 
goals and subjective voices, the testimonio and the crónica. ${ }^{14}$ Alicia Rita Rueda Acedo points out that Poniatowska's subjective stance per the subjects she chose to interview in no way slants her reportages, as Tom Wolfe had suggested such a perspective could: “Poniatowska's subjectivity is open 'neither to scrutiny nor verification' due to the enormous 'weight', respectability and tradition that the writer's voice has in the current journalistic and literary scene". ${ }^{15}$ The Latin American brand of literary journalism was more liberating to Poniatowska, and, at any rate, if she was going to publish in Mexico she had to follow its traditions more than those of the gringos to the north or of the Frenchies across the great pond.

Léziart describes the two types of crónicas in Mexico, both of which Poniatowska produced throughout her career, as the short journalistic crónica written for newspapers or magazines and the book-length historical crónica:

Favoring the short text, closer sometimes to the fable or the short story, or adopting the form of the article of newspaper or magazine, this new chronicle preserves its anchoring in the moment and topicality. In Mexico, it is a manner of writing that contemporary cronistas have used to contradict the dictates of nationalist academicism that equates culture and stereotype. They have also used this fast and easily accessible writing method to defend the ideas of justice and freedom against a hierarchical, closed or even corrupt social and political environment. As we can see, by mimicry or by necessity, the chronicle has adapted to the fluctuations of time to find a sort of orality which suits it well by its proximity to facts and acts. ${ }^{16}$

The journalistic crónica became important in 19th-century Mexico since people did not want to read erudite writers, ${ }^{17}$ and it grew in importance later when it helped expose certain dark truths that the government-influenced press did not want exposed: "The most politically committed chronicles like [...] those of Elena Poniatowska occupied an intermediate space of expression that was freed by a political power less bent than before on muzzling the press". ${ }^{18}$

Mahieux has studied extensively this development of the chronique engagée in Latin American, particularly in Mexico, and details the growing tensions between the state-influenced media machines and the investigative cronistas:

A few decades later, with the repressive political atmosphere of the 1970s and the establishment of media conglomerates that were fully entrenched with government power, this creative complicity between the chronicler and the culture industry receded. The chronicler's public role took on the urgency of political responsibility and revealed a deep concern with the ethics of representation. One way the distance between the chronicler and mass media manifested itself was through the heightened orality of the genre, which turned to fragmented voices as a means to contest the censorship of images by government-controlled media empires. ${ }^{19}$

16 The most "emblematic example" of this shift, Mahieux continues, was Poniatowska's book-length crónica, La noche de Tlatelolco:

This chronicle bypassed the censorship of the press by appearing directly in book form, a move that highlights the growing independence of the genre from the newspaper page and its alliance to other Latin American genres such as the testimonio. In Massacre in Mexico, the vulnerable accessibility of the chronicler hinges on her willingness to listen and to become politically engaged. Poniatowska assumes the task of a transcriber and cedes the role of protagonist to the masses. The chronicler thus blends in with the voices of the crowds in a radical manifestation of the rhetoric of accessibility that had been expressed by chroniclers such as Arlt, who consistently highlighted his public anonymity in the streets of Buenos Aires. ${ }^{20}$ 
17 Poniatowska herself recalled how her initial chronicle on the massacre of the Plaza de las Tres Culturas (Tlatelolco), written just days after the tragedy, was ill-received by her editors: "I took my interview to the newspaper Novedades, but they turned it down because there were orders not to publish a single word about the incident." ${ }^{21}$

It is this explosive environment, where journalists readily lost their jobs and sometimes their lives after exposing government corruption, that we situate Poniatowska's writing, an environment far from the innocuous New York cocktail parties of Norman Mailer's Armies of the Night or Tom Wolfe's Radical Chic and closer to the European reportaż zaangażowany of Ryszard Kapu ściński's Wojna futbolowa and the Latin American testimonio of Rodolfo Walsh's Operación Masacre.

\section{2. “¿Los que huyen sin zapatos?": La noche de Tlatelolco and textual hybridity}

19 With one foot firmly planted on the Plaza de las Tres Culturas and another extended across the Atlantic divide to the squares of other politically agitated nations during 1968, La noche de Tlatelolco manages to speak in the Mexican vernacular and universal lingua franca of trauma. It is a book of its era, but also one for all time, since leaders around the world continue to oppress their nations, and body politics repeatedly rise up against them. It is this dual spacio-temporal identity that lends $L a$ noche de Tlatelolco its worldly appeal and situates it among the best global reportage books of the 20th century. It consists of a visual narrative including forty-four black and white photographs with captions made of quotes taken directly from the book, and a textual narrative divided in two parts, "Taking to the Streets" and "The Night of Tlatelolco". Even though the visual and the textual narratives complement each other, each part of the book constitutes an individual "whole" of Poniatowska's argument and, as such, merits separate extended analysis.

\subsection{Conflict photography}

La noche de Tlatelolco begins with a series of photographs that, for security reasons, carry no credit lines of those who took them (since the Mexican government tried to cover-up the massacre, printing any photographs taken during that fateful night was dangerous for authors). ${ }^{22}$ These photographs offer more than a mere illustration of what had happened but constitute a legal affidavit against the government's official version..$^{23}$ They also serve to distance Poniatowska from the magical realism so popular in Latin American letters at that time, visually grounding the book's textual narrative in historical truth. ${ }^{24}$ The forty-four photographs of this photojournalistic essay constitute a visual narrative that was conscientiously composed and edited to parallel the textual story of the events leading up to the massacre.

21 The visual narrative opens with a July street battle between two rival high school gangs, the Ciudadelos (Citadels) and the Arañas (Spiders), over a recent football match between the teams they supported, and then shifts to photos from demonstrations in August and September 1968 depicting young people, mainly students, marching with banners. The immediate effect of these first two images is to establish both the violence intoxicating the city during this year of global uprising, political turbulence, and civil 
unrest (e.g., the student demonstrations at Warsaw University in March, the assassination of Martin Luther King, Jr. in April, the Parisian soixante-huitards in May, the Chicago Democratic Convention and the quashed Prague Spring in August, etc.), and the quick solidarity established among the students after they encountered a common enemy in the government's oppressive policies and police force.

The photo narrative then shifts to Mexican workers, who soon joined the student demonstrations against the government. To mark the abrupt transition, Poniatowska includes a 1958 photo of railway workers on strike, which carries the following caption: "In 1958, railway workers were alone in their protest. We weren't." ${ }^{5}$ The photo-which was solely Poniatowska's editorial decision to include, as it was not part of the current narrative-seemingly bears her direct political involvement and sympathy with the students and workers, the first sentence being merely descriptive but the second, shorter one ("We weren't") singularly inclusive. And while there is no doubt that she did side with the students' cause (her brother Jan, who tragically died in a car accident two months later, was one of the high school student demonstrators on Tlatelolco that night), the caption should have carried quotation marks, since it did not originally come from her. In fact, the caption was taken from her interview later with Luis González de Alba of the CNH (Consejo Nacional de Huelga / National Strike Committee): "The railway workers who protested in 1958 had no support from the general public. But the students in 1968 did." ${ }^{26}$ The lack of quotation marks here, and elsewhere in the various selected captions, cleverly displays her "mediating authority"27, as Beth Jörgensen describes it, that aligns her with the student movement but frees her from any potential legal morass since, officially, there were not her words.

An image of workers from a decade later that supported the student movement in 1968 follows. Afterward, there are three photos of city women and peasant women marching together with young girls, carrying banners at demonstrations and backing the movement. The early photos show close-ups of a few people involved in the demonstration, which quickly turns into wide-angle photographs capturing the expanse of a crowd of tens of thousands of demonstrators. The clever rhetorical effect here is to show support for the students built up over the later summer months, accelerating as it were in the students' favor. It is also worth mentioning that in the photo-essay Poniatowska underlines women's participation from the beginning and shows their active role in the protests, something she echoes in the textual narrative of her book.

Soldiers start appearing in the photographs immediately afterward. We are shown the military occupation of the University City, soldiers, with bayonets pointed, lining the students up against the wall and frisking them. Tanks quickly descend on the streets. What strikes the viewer is that the once peaceful demonstrations from August have suddenly, by September, turned violent, creating a visible mounting tension in the photographical sequence. By early October, that tension had reached its climax with the massacre: soldiers enforcing the government's orders to quell the demonstration by any means necessary. The photos repeatedly show the evening's attack as being diametrically opposed: soldiers are even seen smiling in one photo, while, in another, abandoned shoes litter the plaza's trodden lawn, its caption reading: "Strewn about on the pavement, among the torn clothing and the plants trampled underfoot, were many shoes most of them women's." 28 In later interviews, Poniatowska often singled out these empty shoes among all the horrific images of that night as a synecdoche for 
tragic loss, not just for the student moment but of the nation's soul in general: "Perhaps the most surprising aspect was the huge number of blood-stained shoes that were scattered around the area, silent witnesses to the disappearance of their owners". 29

The photographs used to capture the aftermath are equally intended to shock readers. We first encounter family members gathered in front of the third precinct building or visiting morgues in search of their dead, wounded, or disappeared loved ones. Next come photos of corpses, bodies of young students, many of them of high school age, lying in puddles of blood. There is also a photo of a young boy shot dead whose caption is taken from a voice tape-recorded by Juan Ibarrola during the shooting: "Who gave orders to do this? Who could possibly have ordered such a thing?" ${ }^{30}$. Further, we find several photos of the incarcerated, from strike leaders to groups of young boys in a jail cell, locked behind bars in front of two men, presumably fathers looking for their captured sons.

The last two photographs project the tragedy into the following weeks. The first photo shows a a group of students and writers at a hearing and, the second, a gathering of young people kneeling besides candles and flowers laid on the Plaza de las Tres Culturas (Tlatelolco Square), commemorating the events that occurred exactly one month earlier. The caption below the photo reads:

On the second of November, All Souls Day, we placed cempazúchitl flowers and candles on the Plaza de las Tres Culturas. There were many Army troops on guard, but suddenly thousands of memorial candles were lighted and hundreds of people popped out from behind the trees and began to pray for their children who had been murdered at Tlatelolco on the second of October. ${ }^{31}$

These final two photos add a sober coda to the previous forty-two photos narrating the events of late summer and autumn 1968; from peaceful marches to tanks in the street to armed soldiers aiming in the direction of the students, to youngsters lined up against a wall to those lying dead on the ground. Together, like the final movement of a symphony, the photos build a palpable tension that crescendos into a climax which, here, returns us to a forlorn, placid state. It is this same structure that Poniatowska's adopts for her textual narratives that follow.

It is important to see how any reprinting of these photos, separated and scattered throughout the text, would disrupt the book's overall rhetorical strategy. Even their arbitrary placement as a complete cahier throughout the various editions of the book, especially those in the middle or at the end, would disrupt the photo sequence's rising tempo, just as inverting any movement in allegro for one in andante would considerably alter the building melodic tension of a symphony.

This visual narrative, then, clearly bears Poniatowska's signature and allow her to sway readers to her perspective even before they encounter the official government texts she reproduces later, a textual narrative that suggests in part that the armed students had opened fire against the soldiers first before they retaliated in self-defense. As Léziart writes, "[...] to anchor the story in reality, the Mexican author has documented herself at length, and selected the photographs very scrupulously, just like the events reported". ${ }^{32}$ However, these photographs do much more than just document the incidents that we are about to read; they provide a visual narrative that authenticates or, at times, counters the textual narrative. Of this visual-textual narrative counterpoint, Bell Gale Chevigny writes: "What engages Poniatowska, I believe, is the 
power of silence transformed into silence heard"..$^{33}$ The silent photos lay witness to the truth of the massacre whispered, voiced and even shouted out in the textual narrative that follows.

\section{2 "Taking to the streets" (Ganar la calle)}

The first part of the textual narrative, entitled "Taking to the Streets", follows the course of the student movement from July 1968 to 1970 . It is organized in a way that we get to know the beginnings of the movement, the particular cases of its members (people talk about their reasons for joining), and the meetings they held. We also hear the voices of random people who support the protestors and those who do not. The massacre, though, haunts this textual narrative from the very beginning. Poniatowska underlines the festive air of the demonstration in the short prologue by comparing it to a fun fair, but quickly adds a caustic commentary: "the guns in the shooting gallery are aimed at them [the students]". ${ }^{34}$

31 In the second paragraph of her prologue, still on the very first page of the crónica, Poniatowska writes:

The owner of the shooting gallery handed out the rifles to the police, to the army, and ordered them to shoot, to hit the bull's eye, and there the little tin-plated creatures were standing, open-mouthed with astonishment and wide-eyed with fear, staring into the rifle barrel. Fire! The sudden blinding flash of green flare. Fire! They fell, but this time there was no spring to set them up again for the next customer to shoot at; the mechanism was quite different on this fair; the little springs were not made of metal but of blood; thick, red blood that slowly formed little puddles, young blood trampled underfoot all over the Plaza de las Tres Culturas. ${ }^{35}$

Just as with the visual narrative of the photo-essay, where Poniatowska begins by juxtaposing kinetic (the football street brawl) with potential (the peaceful marches) violent energy, the textual narrative opens on a rhetorical device that creates meaning and rhythm through unanticipated contrast. The extended metaphor of the fun fair shooting gallery, which makes the protestors metallic ducks (that will not spring back when shot) and the government forces innocent boys trying to impress with their marksmanship, heightens the textual tension through bathos. While most of us have shot a BB gun at a fair or have seen others do it, we would never equate protesting students with rotating ducks or BBs with real bullets. And yet, the Mexican soldiers did. The effect Poniatowska creates with this metaphor is what Hannah Arendt discovers at the end of her five-part series of "Reporter at Large" articles published in the New Yorker in early 1963 that would eventually become Eichmann in Jerusalem-itself no small example of literary journalism: "[...] summing up the lesson that this long course in human wickedness had taught us-the lesson of the fearsome word-and-thoughtdefying banality of evil. ${ }^{36}$ The same institutional indoctrination that underscores football hooliganism is responsible for a military shooting down its fellow countrymen and women. Poniatowska does not wish to unburden the soldiers of their responsibilities in the killings (far from it, in fact) but, like Arendt, she does recognize that the real evil lies in those who, like the owner of the shooting gallery, gave the banal orders to shoot the "metallic ducks" in the first place. 
events of the bloody night of 2 October to which the whole second part of the book is dedicated. Again, though, one needs to consider the rhetorical strategies of the photoessay in its efforts to build up tension. To merely say the government was at fault would openly align the journalist Poniatowska with the student demonstrators, and subject her book to immediate censorship by governmental degree; to show that fault instead lay solely with the government, and leave the reader to connect the proverbial dots, would not only bolster the cronista Poniatowska's objectivity and authorial voice but also free her book from any future charges of libel. Poniatowska was, of course, hardly objective in the manner in which she edits the montage of her textual narrative, just as she was not unmotivated in selecting and ordering the photos of her visual narrative. In recalling Beth Jörgensen "mediating authority", it becomes clear that Poniatowska is simply repeating the rising crescendo pattern in this textual part, slowly building the backstory to the massacre while inscribing it into contemporary Mexican history.

This crescendo pattern is evident in one of the most important features of La noche de Tlatelolco: its "collage" composition of "voices bearing historical witness". ${ }^{37}$ From the very beginning of Poniatowska's crónica, we encounter the book's polyphonic and dialogical nature:

- a banner carried at the students' demonstration of 18 August 1968 ("PEOPLE, UNITE, DON'T ABANDON US, PEOPLE, UNITE, PEOPLE, DON'T ABANDON US, PEOPLE, UNITE”38);

- a two-page long introduction signed by the author wherein she compares the student demonstration to a fun fair suddenly gone south;

- fragments of interviews with members of the National Strike Committee, students, random mothers and fathers of Mexican families, teachers, $\mathrm{CNH}$ delegates imprisoned in Lecumberri prison, and different representatives of the working-class (such as factory workers, beauty salons operators, messengers, dressmakers, tailors, etc.). Some of the voices are in favor of the students and their movement, while others are against it;

- chants from demonstrations ("Mé-xi-co-Li-ber-tad-Mé-xi-co-Li-ber-tad-Mé-xi-co" ${ }^{39}$ );

- street posters (like "PEOPLE, OPEN YOUR EYES!" ${ }^{40}$ );

• student slogans (“DOWN WITH MUMMIES!"41)

- placards ("DOWN WITH CUETO AND HIS HOUND DOG MENDIOLEA ${ }^{42}$ "), referring to the chief of police Luis Cueto and his deputy chief Raúl Mendiolea;

• signs posted around the university (“JUÁREZ, WHAT SHOULD WE DO NOW?" ${ }_{43}$ );

- fragments of press articles from various Mexican newspapers, etc.

As Christopher Harris points out: "The text is hybrid, because it combines photojournalism, authorial statements, testimonial statements from survivors and political prisoners as well as extracts from documentary sources such as political speeches and hospital records. It defies easy classification as a work of history or fiction." ${ }^{44}$ Ultimately, Poniatowska's choice, arrangement and use of legends per the photographs and her decision to cite from the various the stories and headlines of the national press serve to demonstrate how the government attempted to control and manipulate peoples' attitudes via the press about the students, thereby justifying its actions and covering up its crimes. In Carmen África Vidal Claramonte's words,

The novel [sic] does not use a simple dichotomous frame in which it would be very easy to place victims and executioners face-to-face; rather, the author creates a collage, as she calls it, so that she achieves a multilayered text charged with heteroglossia and polyphony that challenge the authorised monochromatic version of what took place. ${ }^{45}$ 
It is important, however, to point out that Poniatowska does not present an objective casebook with complete interviews and printed materials. Her testimonial writing mixes her selected lines from personal accounts, slogans, graffiti, one-liners, poems, fragments of news, etc. It is an account based only in part on official documents and is thus as mediated as the government documents themselves to a certain extent. As the subtitle states, it gathers Testimonios de historia oral from professors, students, school teachers, workers, union leaders, lawyers, housewives, students' parents, foreign journalists and other observers. Some speak just once, others several times. Some are in favor, others are against. And although Vidal Claramonte questions the ethics behind Poniatowska's "intralingual translations" ${ }^{46}$ of these oral narratives, she does admit that the microhistories are nonetheless important because they bring what was "previously considered peripheral into the center of our narrative" ${ }^{47}$-in effect, giving a voice to those who had been repeatedly silenced by those in power. While no less biased than the government's accounts of the events the night of 2 October 1968, La noche de Tlatelolco does at least tip the scale toward factual representation.

This variety of documents thus enables Poniatowska to construct an archive that counters the official narrative. Veracity lies not in one voice, one document, one perspective, but in the collective voices of civil society, including its lying government and prejudiced press, both of whom are given space in Poniatowska's book. ${ }^{48}$ At the same time, like a puppet master (to invoke her earlier fun fair metaphor), she records and reports, cuts and pastes, blends and deflects different voices to make her political points more compelling and persuasive. ${ }^{49}$ Altogether, this collage of genres and discordant voices allows Poniatowska to recreate the atmosphere of the time, showing the rage, enthusiasm, and desolation of the people, as Monsiváis points out:

The sentences synthesize the process, the statements illuminate the spirit of the movement. By fragmenting and choosing the most direct testimonies, the deepest reasons of 68 and the conversion of the political confrontation into an existential discovery of the limits and scope of power are essentialized..$^{50}$

Critics have consequently categorized La noche de Tlatelolco as an engaged documentary narrative on the grounds that there is a "continuity between imaginative literature and documentary in Latin American culture ${ }^{51}$ " which looks to sway as much as to inform its audience. La noche de Tlatelolco's patchwork of official texts and testimonies by various people-present or not at the massacre - may give it an eerie, ghostlike feeling, like riding on a driverless bus. And Poniatowska does seemingly leave herself out of the book's driver's seat. But make no mistake: she is in complete control of her narrative's slanted message. Apart from the montage's editorializing jump cuts, not unlike those Sergueï Eisenstein used to his polemical advantage in Potemkin (1925), Poniatowska does appears from time to time through the skeletal "E.P." signature that she attaches to five interpolations (her prologues, her 1970 press article, and her statement at Jan's burial). These initials "sign" the words as her own among the book's heteroglossia without fully introducing Poniatowska as their author. The strategy makes the book simultaneously hers and the students', what Beth Jörgensen describes as her "framing" process:

In tribute to this process Poniatowska casts herself in the text as an editorial figure and employs various strategies to efface her own individual presence. Nevertheless, she cannot wholly abdicate her mediating authority as the editor. The editorial figure is at once accessory and essential to the voices she records, and at once marginal and central to their story. ${ }^{52}$ 
is most important is that Poniatowska is not trying to hide behind the students' and others' words, is not attempting to "abdicate" her responsibility in the book. She may be their editor, but she is also their amanuensis. She is here journalist-researcher and, as such, imposes her own personality on the text, giving it a physical appearance, a way of speaking, a manner of gesturing-all uniquely her own and theirs simultaneously. Poniatowska's acquaintances in the book react to her uniqueness in the same way acquaintances of sociologists or anthropologists react to them. ${ }^{53}$ The anthropologist's own person is, in fact, a significant factor in her choice of subjects to interview-refusing some and persuading others to cooperate-just as it is for a journalist in writing up a news story. What has the illusion of objectivity is purely subjective without the obvious telltale signs of a first-person narrative. In that way, Poniatowska can remain both absent from her text and very much present throughout it.

This absence/presence duality is equally found in the way she organizes the cut-up documents and testimonies. Most are based on themes that, like the arrangement of the photographs, provide a multi-tiered layer of meaning and textual rhythm. Interviews, for instance, are cut into pieces and interspersed and intersected according to the effect she wishes to elicit. The first topic is the student movement itself, wherein Poniatowska gathers personal declarations and opinions from the young people as to why they joined the movement. Their voices are interlaced with chants and banners from different demonstrations that serve to show, like the shift from the football street fight photo to those of the collective marches, the movement's consolidating gestalt: individual voices can be selected at random but, when pieced together, they form a choir in perfect harmony and reverberating round. For example, in between the declarations of people who joined the movement we encounter the actress Margarita Isabel, who pronounces:

I joined the Student Movement simply because one day the granaderos [the riot police] turned up at the INBA [Instituto Nacionale de Bellas Artes / the National Institute of Fine Arts] with police dogs and chains and hauled everybody off to jail. And the INBA hadn't even come out and said whether it supported the Movement or not! (I'm rather inclined to think it didn't, right?) This arbitrary invasion made many of us actors and actresses aware of what was happening, and we decided to join the students and help them, really help them, not just march arm in arm in demonstrations or yell at the top of our lungs in meetings... So then we formed an actors' brigade ${ }^{54}$.

41 About fifteen pages later, when Poniatowska shifts her topic to the subject of the meetings themselves and the way the movement was working on how to persuade the people to its rights, Poniatowska inserts another two-page long testimony by Margarita Isabel, who explains what sort of happenings the movement had organized. ${ }^{55}$ Thirty pages later, Poniatowska interpolates another of Margarita Isabel's stories, in which she narrates how she was being followed by a plainclothes policeman, jumped into a car to evade him, and, when driving very fast and trying to avoid being caught, ran into another handsome guy and started imagining that he may not only rescue her from the police but even initiate a romance, when, suddenly, the second guy turned out to be a plainclothes policeman, too. ${ }^{56}$ Twenty pages after that, when Poniatowska touches on the subject of family and how different parents react to the movement, she again quotes Margarita Isabel, who explains the situation she has with her mother and the very different points of view they both represent: "When I talked with my mother 
about the Student Movement and the whole student bit, she must have imagined all kinds of things, because she said to me, 'Why don't they send the whole lot of them to Moscow to worship the Devil himself?'57" Finally, ten pages later, when giving attention to the women involved in the movement, Poniatowska again quotes Margarita Isabel, who, this time, talks about how some kids helped her fill the empty gas tank of her car by stopping a man in a big fancy car and pouring the gas from his tank into hers. ${ }^{58}$ Like a film documentarist, Poniatowska frames her subject, editorializes in her edits and persuades through affect and aesthetics.

Given all this, La noche de Tlatelolco becomes another iconic example of Mikhail Bakhtin's polyphony. Although Bakhtin's theory of the dialogic and the plurality of voices relates to the novel in general, and was applied to Dostoevsky's poetics in particular, it is readily applicable to Poniatowska's crónica. As Bakhtin maintained,

At the base of the genre lies the Socratic notion of the dialogic nature of truth, and the dialogic nature of human thinking about truth. The dialogic means of seeking truth is counterposed to official monologism, which pretends to possess a readymade truth, and it is also counterposed to the naive self-confidence of those people who think that they know something, that is, who think that they possess certain truths. Truth is not born nor is it to be found inside the head of an individual person, it is born between people collectively searching for truth, in the process of their dialogic interaction ${ }^{59}$.

This dialogic interaction is visible throughout La noche de Tlatelolco, most notably in the generational conflict Poniatowska exposes between youngsters and their parents. First, she quotes a father who is against men sporting long hair, then a mother who is against girls wearing short skirts. ${ }^{60}$ Later, Poniatowska juxtaposes these voices with other parents, who are themselves very much in favor of the movement and young people. One of the mother's states, for instance, that she is delighted by young people, while another mother declares she likes the way young people live now. ${ }^{61}$ Then, she cuts to the voices of students who say they cannot communicate with their parents, one of them pronouncing: "Communicate with my old man and my old lady? Are you kidding?"62 Victoria Garfias Madrigal, a student at the Faculty of Engineering at the Universidad Nacional Autónoma de México (UNAM), confides to Poniatowska: "The only time I get along with my parents is when we go to the movies, because nobody talks then". ${ }^{63}$

The dialogic method also allows Poniatowska to show that the one truth proclaimed by the government, and echoed in the Mexican dailies-both of which she profusely produces throughout the book-simply does not exist. The collage of different, at times cacophonic, voices and documents, allows her not only to give voice to the voiceless but also to include as many possible perspectives as possible, all without proclaiming one, transcendental truth to the tragic events on the night of 2 October 1968. She shows the movement, then, from both inside its many concentric circles, and from outside, juxtaposing those voices against students with those supportive of the movement and its fight.

Another particularity of "Taking to the Streets" is that if, at first, we encounter a Mexican youth movement imbued with hope and convinced of its power to institute change, the closer we get to the second part of the book, the less carnivalesque their commitments sound. While the early themes of the collage cut-ups cover the history of the movement, the arguments for and against the students, the students' way of life, the movement's organization, etc., the closer we approach the night of the massacre on 
Tlatelolco, the more violent the themes become. Like the crescendoing visual violence in the photographs, the textual violence also progresses apace: descriptions of arrests, tortures, and interrogations that took place before the day of the events or after 2 October 1968 prepare the reader for the horrors that await them in the second part.

There is, for example, the declaration of Víctor Vállela, writer and member of the Pen Club, who recounts one violent incident to Poniatowska in an interview:

After the soldiers shot me in the CU on September 19, 1968-I was hit in the femur and the bullet came within a few millimeters of severing my femoral artery-I was in the November 20 hospital for two months, and I never told anybody how I'd gotten hurt, not even other kids who visited me, because there was talk going around that there were "stoolpigeons" and "finks" everywhere; there was fear in the air, an atmosphere of absolute mistrust ${ }^{64}$.

In another testimony, a mother recalls how the police arrested her husband, and, when she finally saw him, she told Poniatowska:

I was shocked when I finally saw him: had a three-day growth of beard and a terribly anxious expression on his face, and his suit was a mass of wrinkles. He was terribly surprised when he saw us, because usually the only reason they ever took prisoners out of their cells was to beat them. ${ }^{65}$

One of the members of the $\mathrm{CNH}$ also details for Poniatowska how he was punched in the stomach and kicked in his testicles, and, when he was doubled up because of the pain and fell to the floor, the policemen started to kick him from head to foot. Then they gave him electroshocks to his testicles, rectum and mouth, all the while asking him more and more questions. ${ }^{66}$ Another student imprisoned in Lecumberri mentions that, during his interrogation, the police kept giving him electroshocks with an iron prod on different parts of his body, and left him half-conscious on the floor. ${ }^{67}$ Another student recounts:

Then they took us down to solitary, along with some ninety other prisoners, and shut us up in a cell meant to hold fifteen people. There was sewage leaking from the pipes and the toilets were overflowing; there was no light and no ventilation and every two hours the agents wet us down with special hoses. ${ }^{68}$

In sum, the last seventy pages of the first part of La noche de Tlatelolco contain accounts of imprisonment, interrogation, and torture. The textual images recall those visual ones in the photographs collected earlier, driving home her book's antigovernment message. Recognizing, no doubt, that the sudden shift to the violence excruciatingly detailed in the second part might undercut these earlier testimonies, or make the later ones appear redundant, Poniatowska concludes this section with fragments from Latin American poems about overcoming one's oppressors. It is not just to summarize the students' struggle from the 13 August demonstration to 1970 that she cites from a José Martí poem about a new people in the Americas asking for hard work and honesty in politics ${ }^{69}$, or from an anonymous poem about Latin American "first grammar lesson"; ${ }^{70}$ she cites from these panegyrics to force us also to look beyond the events that will be described in the following pages, and to a time when, perhaps years later, those who died on Tlatelolco Plaza will not have been forgotten. Rhetorically speaking, she elevates the dead to heroic heights just before showing us how they died, preparing them to become martyrs and us to ask the universal question "why?" 


\section{3 “The Night of Tlatelolco" (La noche de Tlatelolco)}

visual and textual images of violence and torture that Poniatowska could have easily ended her crónica here. Even despite her near narrative absence throughout the book, there would have been little chance of a reader missing her point. So why continue? Arguably, the literary journalist Poniatowska has concluded her work at this point, but the historian Poniatowska is only just beginning, for this second textual narrative, entitled "The Night of Tlatelolco", concentrates on the events of that night on Tlatelolco Plaza so as to ink them permanently into history, just as the government was setting its permanent record down in the various Mexican dailies. At this point in $\mathrm{La}$ noche de Tlatelolco, the reader is no longer taking sides but weighing historical facts and determining the journalistic half-life of mediatized truths.

two starts with a fragment of the newspaper article published on 8 October 1968 "We must bear witness to our surprise and indignation at the events that night at Tlatelolco, when barbarism, primitive savagery, hatred, and the most vicious impulses held sway". ${ }^{71}$ Following this citation is a poem by Rosario Castellanos ${ }^{72}$ and Poniatowska's second brief introduction ${ }^{73}$-again signed with only her initials-where she explains that the majority of the interviews that follow were recorded in October and November $1968 . .^{74}$ The subsequent textual fragments are all taken from the following morning's headlines in the Mexican dailies, all of them contradictory on the basic facts of the massacre, including death tolls and those responsible. One paper, $E l$ Sol de Mexico, even declares that the soldiers only fired upon the students in selfdefense when snipers that the students had placed on various buildings around the plaza began shooting at them (later, video taken during the even proved the exact opposite was true):

FOREIGN INTERLOPERS ATTEMPT TO DAMAGE MEXICO'S NATIONAL IMAGE The Objective: Preventing the Nineteenth Olympic Games from Being Held. Sharpshooters Fire on Army Troops in Tlatelolco; One General and 11 Soldiers Wounded; 2 Soldiers and More Than 20 Civilians Killed in a Terrible Gun Battle. ${ }^{75}$

A short, seven-page long reportage, which Poniatowska signs with her initials, follows, wherein she presents the exact chronology of the events, framing the story that is about to be narrated. This story is made of different interviews she had conducted and later edited. By the end of the second part, all accounts and testimonies of the events shift from evidence into opinion, calling the future of the country into question.

What is especially visible in this second part is that Poniatowska cuts her interviews into smaller segments and intermingles them with other sources, in effect slowing down the textual narrative's rhythm. For the reader, this rhetorical strategy is akin to watching the events play out in slow motion, allowing time to perceive the details previously presented in rapid fire style. Since the emotive goals of the narrative have already been achieved, there is no need to reproduce them. This section of the book, then, is more about preserving the history of the event, and determining who will finally authorize it for future generations. One example is the protracted narrative style is the story of Diana Salmerón de Contreras, which encapsulates the events on Tlatelolco Plaza over ten pages. 

her younger brother, fifteen years old Julio, was shot dead by the police; she continues on how she asked for help, how she went with Julio in the ambulance and was trying to talk to him but he never answered her. Diana's testimony is cut into short fragments and interpolated with different accounts of the shooting. The first segment appears when she talks about the chaos that started on the Plaza. Diana recounts that her brother told her not to let go of his hand, and that they were trying to reach the part of the square with the ruins:

Some students were lying there on the ground between us, some of them dead and others wounded [...]. The shouts, the cries of pain, the weeping, the prayers and supplications, and the continuous deafening sound of gunfire made the Plaza de las Tres Culturas a scene straight out of Dante's Inferno. ${ }^{76}$

ext, Poniatowska reproduces the testimony of a mother of a family begging for a doctor, then, later, the testimony of Berta Cárdenas, who was living in a Tlatelolco housing unit and who explains that the soldiers and the police would not even let the ambulances through to help the injured. There is then testimony of an anthropologist who says she warned the students about the Plaza being a trap, and reference to a hippie button found on the Plaza that reads "I love love". From here, Poniatowska returns us to Diana Salverón's story, as she discovers that her brother is not responding to her calls, and she is afraid he might be wounded. Just as Diana is trying to get the answer from her brother, wondering what had happened to him, Poniatowska interpolates her testimony with press articles published on October 3 in El Universal and Excelsiór. The newspapers' retrospective and funereal tones contrast strikingly with Diane's pulsating testimony. While Jorge Avíles R.'s account from El Universal neutrally describes how he saw "many others struck by bullets fall to the ground", and the Excelsiór news story mathematically lists the "number of dead bodies lying in the Plaza de las Tres Culturas", Diana's says:

Little brother, speak to me... Please, somebody get him a stretcher! I'm right here, Julio... a stretcher! ...Soldier, a stretcher for somebody who's been wounded... What's the matter little brother? ...Answer me, little brother... A stretcher!...77.

By juxtaposing Diane's personal account of the massacre with these published news stories in documentary jump-cuts, Poniatowska not only augments the horror but also puts into clearly relief the various, often contrasting, perspectives of that night.

In general, "The Night of Tlatelolco" is much more visual than "Taking to the Streets", if by visual we understand a close-up depiction of the event from ground zero. That could partly explain why the English publisher decided to place Poniatowska's photoessay at the beginning of the second part of the book, disrupting to a certain extent Poniatowska narrative strategy in the book. There is, for example, a testimony of Dolores Verdugo de Solís, who says: “My daughter's blood was tracked all over the Plaza by the shoes of youngsters running from one end of it to the other"78 or a gradeschool teacher who confesses: "The majority of the corpses were lying face down, swelling in the rain, but there were also some lying face up. They looked like trampled flowers, like the mud-spattered, crushed flowers planted around the Chihuahua building". ${ }^{79}$ There is also a testimony of one of the students who says he saw a group of six-year-old children running, when suddenly one of them fell to the ground and the other started shaking him, trying to wake him up:

He began to pull at him as though that would revive him. "Juanito, what's wrong with you?" he asked him. He obviously had no idea what death was, and was never 
to find out that his little friend was dead, because his questions suddenly were heard no more, just a moan. [...] Then the bullet hit him! ${ }^{80}$ and Poniatowska does seemingly try to show as well their points of view. But it soon becomes clear that she uses the pro-government texts to discredit them or to underline the fact that the government and the army were controlling the massacre's narrative and thus suppressing the real story from the people. ${ }^{83}$ On the closing pages, she produces a couple of statements that clash with all of the previous testimonies. Daniel Guian, for example, director of an insurance company from France who has come to Mexico to attend the Olympic Games, retorts: "I understand very well why the Mexican government reacted as it did, and if I had been in the authorities' shoes, I would perhaps have been obliged to behave in the precisely the same way". ${ }^{84}$ Perhaps, Poniatowska seems to be implying here, if Daniel Guian had actually been in the students' shoes, those scattered about the Plaza and covered in blood, he would have spoken differently.

\section{Conclusion: a question of translation?}

61 Just one of Poniatowska's works of literary journalism has ever been translated into French, La Nuit de Tlatelolco, but only just recently; and none has been translated into Polish. It seems instead that the French are drawn more to her novels or biographical fiction: Lilus Kikus ([1954] 2005); Cher Diego, Quiela t'embrasse (Querido Diego, te abraza Quiela [1978] 1993), a collection of fictional letters from Angelina Beloff to Diego Rivera; La fille du philosophe (De noche vienes [1979] 1993), Tinísima ([1992] 2014) and Leonora ([2011] 2012). Perhaps the French translation of Hasta no verte, Jesús mío, Vie de Jésusa ([1969] 1980), could be considered as nonfiction testimonio, since Poniatowska had used a tape recorder to capture the life of her protagonist in situ before putting her life down on paper. Like others, though, including her biographer Michael K. Schuessler, Poniatowska herself does not see the book as literary journalism, but rather as an updated version of the Spanish "picaresque novel" 85 , an anthropological novel in the 
same vein as Cuban writer Miguel Barnet's 1968 Biografía de un cimarrón (Biography of a Runaway Slave). In translating La Nuit de Tlatelolco, perhaps French publishers will begin a new trend and correct their earlier oversight.

Polish translations of Poniatowska's work do not fare much better: Do sĘpów pójdĘ (Hasta no verte, Jesús mío [1969] 1976) ${ }^{86}$; Kochany Diego, całujĘ CiĘ, Quiela (Querido Diego, te abraza Quiela [1978] 1986); Jedyna w swoim rodzaju (Dos veces única [2015] 2016), about Maria Guadalupe Marín Preciado, or "Lupe Marín", the first wife of Diego Rivera, and then Jorge Cuesta, a poet and critic; and Leonora (Leonora [2011] 2017), a historical novel about the surrealist painter Leonora Carrington. In a country like Poland where literary journalism has been popular since at least the 1950s, the lack of a single translation of Poniatowska's crónicas, in particular the powerful book La noche de Tlatelolco, is surprising to say at least. Is it merely a question of classification or nomenclature? Or are there other biases and factors at work here? Among the many excuses given by Polish editors, translators and Latin American literature scholars, we can formulate the following three hypotheses behind this lacuna: political, literary, and journalistic reasons.

In terms of political reasons, La noche de Tlatelolco was published in Mexico in 1971 and narrated events that took place in 1968, the same year that France and Poland both experienced their own unprecedented political crises. In France, the disillusioned soixante-huitards took to the streets for seven weeks beginning in May 1968, protesting against Capitalism, consumerism and political indifference-a revolution that seemingly takes a curtain call every decade or so. Similarly, Polish students and disgruntled youth took to the streets in March 1968 to protest against the Communist regime of the Polish People's Republic, resulting in the suppression of student strikes by security forces in all major academic centers across the country and the subsequent repression of the Polish dissident movement. As Polish translator Carlos Marrodán Casas affirms, the publication of Poniatowska's book in Europe could have easily opened up fresh wounds. After all, her works openly criticized the Mexican government and sided with the protesters, dissident, antiestablishment political views that were unwelcomed by both the right French and the left Polish governments in power at that time.

Moreover, the tragic events of 2 October 1968 events in Mexico City were largely masked or ignored in the French and Polish press. Le Monde did not cover the story in the days that followed, even in the few articles dedicated to the opening of the Olympic Games. There is brief fait divers on 5 October about a few Dutch students occupying the Mexican embassy in Amsterdam for half an hour out of solidarity "avec les étudiants et travailleurs mexicains"-but no reason is given for the demonstration. It is not until a 7 October article about the "l'inquiètude" that "le mouvement de contestation universitaire" would have on the Games that the "fusillade" was even mentioned. ${ }^{87}$ In Poland, nobody even knew about what had happened in Mexico City. Even today, after reading Chilean writer Roberto Bolaño's Los detectives salvajes (The Savage Detectives, 1998) or Amuleto (1999), both of which refer to the student massacres in Mexico, the average Polish or French reader would have only the slightest idea about these historical events.

There were also literary reasons as to why Poniatowska's literary journalism was not translated into French or Polish for decades. In the 1970s, both countries were smitten with writers of the Latin American Boom. Although the majority of these writers were 
also journalists (e.g., Alejo Carpentier, Gabriel García Márquez or Mario Vargas Llosa), they became widely known only as novelists. Their journalistic or quasi-journalistic pieces were avoided by Polish publishers, who knew from the experience that they would not sell. For example, all of Gabriel García Márquez's "worst" sellers in Poland deal, to certain extent, with journalism ${ }^{88}$ : Relato de un náufrago (1955/1970, The Story of a Shipwrecked Sailor) was first published in French only in 1979 as Récit d'un naufragé, and in Poland in 1980. It seems that French and Polish readers of Latin American prose were looking mainly for novels of magical realism. That could also explain why Poniatowska's crónica on the students' massacre did not interest French or Polish publishing houses.

Finally, there are the journalistic reasons. During the 1960s and 70s, Poland experienced the golden age of Polish literary journalism (arguably, France did not have such an age, though the literary journalism of Jean Hatzfeld or Patrick de SaintExupéry would appear two decades later). The Polish School of Reportage included many prominent best-selling author-journalists, such as Jerzy Lovell (Krakow school), Krzysztof Kąkolewski, Andrzej Mularczyk, Ryszard Kapuściński, Wiesław Górnicki, Stefan Kozicki or Hanna Krall, just to name a few. Many Polish publishing houses (such as Iskry or Czytelnik) also had entire collections dedicated to Polish literary journalism, as in Poland reportage was extremely popular and read more than fiction. It seems that, during those years, only two foreign literary journalists had gained any popularity, the Czech Egon Erwin Kisch and the Italian Curzio Malaparte. Moreover, there were several Polish reporters covering Latin America already, such as Arkady Fiedler and, later, Ryszard Kapuściński. Simply put, there was no need for Poniatowska's books in Poland. It was only after Poniatowska received the Premio Cervantes award in 2013-for her "brilliant literary trajectory in diverse genre, her special style in narrative and her exemplary dedication to journalism, her outstanding work and her firm commitment to contemporary history"-that a Polish publisher bought the foreign rights to her fiction.

What these three hypotheses suggest-and they are just hypotheses, not conclusions, as each would require extensive research beyond the limits of this paper-is that it was easier, and perhaps safer, in France and in Poland to see Poniatowska more as a fiction writer than as a politically-engaged literary journalist. Consequently, her nonfiction has not been given its rightful due, at least not yet.

\section{NOTES}

1. B. Chevigny, "The Transformation of Privilege in the Work of Elena Poniatowska", Latin American Literary Review, vol. 13, $\mathrm{n}^{\circ}$ 26, 1985, p. 49-50.

2. I. Tauzin-Castellanos, "Jardín/es de Francia en la obrade Elena Poniatowska", paper presented at the conference "La emoción del texto. Diálogo entre Historia y Literatura" - CA México Francia, Benemérita Universidad Autonóma de Puebla, 14-15 June 2018, p. 3: "Ramillete de crónicas y entrevistas de figuras de la cultura francesa en Ciudad de México o en París". Unless otherwise specified, all translations in this article are our own. 
3. E. Poniatowska, Jardín de Francia, Mexico City, Fondo de Cultura Economic, 2008, p. 104: “¿Qué le pasa a usted en la garganta? ¿Tiene anginas?" and "No hay conversación possible".

4. B. Jörgensen, The Writing of Elena Poniatowska: Engaging Dialogues, Austin, University of Texas Press, 1994, p. 5.

5. R. Herrscher, "Elena Poniatowska Finds Her Place: From Polish Princess to Recreator of the Voice and Champion of the Mexican Oppressed", paper presented at the conference "SBPJor Associação Brasileira de Pesquisadores em Jornalismo", $15^{\circ}$ Encontro Nacional de Pesquisadores em Jornalismo. ECA / USP - São Paulo, November 2017, p. 11.

6. S. Poot Herrera, Viento, galope de agua. Entre Palabras: Elena Poniatowska, Mexico City, Oro de la noche Ediciones, 2014, p. 165: "En el recorrido aparecen, de modo alternado, la entrevista, la crónica y la ficción-novela, cuento-, el ensayo, la crítica de arte, el libro híbrido, la ciencia pura, arte de artes que Poniatowska cruza con la literatura".

7. B. Miller, "Interview with Elena Poniatowska", Latin American Literary Review, vol. 4, $\mathrm{n}^{\circ}$ 7, FallWinter 1975, p. 76.

8. F. Léziart, "La chronique au Mexique: évolution et perspectives", in América, vol. 49; La Chronique en Amérique latine XIX ${ }^{e}-\mathrm{XXI}^{e}$ siècle, vol. 2, Françoise Aubès and Florence Olivier (eds.), Paris, Presses Sorbonne Nouvelle, 2016, p. 37.

9. D. and W. Young, "The New Journalism in Mexico: Two Women Writers", Chasqui: revista de literatura latinoamericana, vol. 12, n 2/3, Feb.-May 1983, p. 75: "Elle s'est beaucoup inspirée du mouvement né aux États-Unis dans les années 1950 sous le nom de 'New Journalism' dont le but était d'élever le journalisme au niveau de la littérature par l'utilisation de techniques narratives destinées à transmuer le récit de la réalité".

10. V. Mahieux, Urban Chroniclers in Modern Latin America: The Shared Intimacy of Everyday Life, Austin, University of Texas Press, 2011, p. 166.

11. J.S. Bak, "Introduction", Literary Journalism across the Globe. Journalistic Traditions and Transnational Influences, eds. J.S. Bak and B. Reynolds, Amherst, University of Massachusetts Press, p. 4.

12. M. Schuessler, "Mexico's Tlatelolco Massacre, and Its Echoes Today", The Nation, 3 Aug. 2018. Available at <https://www.thenation.com/article/mexicos-tlatelolco-massacre-echoes-today/> [consulted 2 Jan. 2020].

13. F. Léziart, p. 38: "Le journaliste mexicain avait, en fait, pour fonction de servir d'intermédiaire entre une classe moyenne éclairée et les couches inférieures de la société". B. Jörgensen adds in "Framing Questions: The Role of the Editor in Elena Poniatowska's La noche de Tlatelolco", Latin American Perspectives, vol. 18, n 3, Summer 1991, p. 88: "Once an outsider, a foreigner, through a constant and active searching out of the Other she has created for herself a Mexican identity. Mexico has supplied a lack she felt in herself, and in her work she has recuperated for Mexico a part of itself, a part it may consider extra, secondary, or subordinate: the silenced voices, the anonymous faces, the darkened pages of history; all are on society's margins, another kind of framing figure which in fact penetrates to the center of her nation's collective life".

14. Her use of the testimonio and the interview, as in Domingo 7, where she records interviews with seven Mexican presidential candidates during the 1982 elections, feed into her crónicas.

15. A. Rueda-Acedo, Miradas transatlánticas: El periodismo literario de Elena Poniatowska y Rosa Montero, West Lafayette, Purdue University Press, 2012, p. 49-50: "Esta subjetividad de Poniatowska no '[es] sometida a escrutinio ni comprobación' debido al enorme 'peso', valor de respetabilidad y tradición que la voz de la escritora tiene en el panorama periodístico y literario actual".

16. F. Léziart, p. 35: "Privilégiant le texte court, proche du conte parfois ou de la nouvelle, ou bien adoptant la forme de l'article de journal ou de revue, cette nouvelle chronique conserve son ancrage dans la périodicité et l'actualité. Au Mexique, c'est une forme d'expression dont les 
'écrivains-journalistes' (comme on les nomme) de la période contemporaine se sont servis pour contredire les diktats de l'académisme nationaliste assimilant culture et stéréotype. Ils ont aussi utilisé ce mode d'écriture rapide et facilement accessible pour défendre les idées de justice et de liberté face à un environnement social et politique hiérarchique, fermé ou même corrompu. Comme on le voit, par mimétisme ou par nécessité, la chronique s'est adaptée aux fluctuations du temps pour retrouver une sorte d'oralité qui lui sied bien par sa proximité des faits et des actes". 17. F. Léziart, p. 36: “ces chroniques se dégage généralement une certaine légèreté [...]".

18. F. Léziart, p. 37: “des chroniques plus engagées comme [...] les textes d'Elena Poniatowska ont occupé un espace d'expression intermédiaire libéré par un pouvoir politique moins appliqué qu'auparavant à museler la presse".

19. V. Mahieux, p. 165.

20. V. Mahieux, p. 165.

21. Qtd. in M. Schuessler.

22. Many Spanish editions of La noche de Tlatelolco exist, and the placement of the photos vary per the edition. Regardless of whether they are reproduced at the beginning, in the middle or at the end of the book, the photos always appear collectively, forming a complete visual narrative, and are not scattered about the text. In the English translation of 1993, the one used for this chapter, the photos appear in the middle of the book, thus at the beginning of the second textual part, whereas in the first English edition of 1975, they appear at the end of the book, following the chronology.

23. D. Sorensen, "Tlatelolco 1968: Paz and Poniatowska on Law and Violence", Mexican Studies / Estudios Mexicanos, vol. 18, $\mathrm{n}^{\circ}$ 2, Summer 2002, p. 316. As Sorensen notes: "The authority of the photographic proof has a documentary function, which Poniatowska employs to multiply the ensuing testimonios de historia oral" (318).

24. N. Gardner and M.R. Martín Ruano, "Reescritura y paratextualidad en La noche de Tlatelolco: la imagen visual en la traducción y la reedición como elemento neutralizador del realismo mágico", Bulletin of Spanish Studies, vol. 92, nº 7, 2015, p. 1079-1091. As the authors note: "Las imágenes que forman parte del libro son un elemento que aleja el texto de modo definitivo del realismo mágico tan prevalente y popular en la América Latina de la época porque ensamblan la narración con lo ocurrido en la dimensión visual [...] estas pruebas gráficas fijan los eventos en un momento concreto de la realidad, que no es preciso imaginar porque se puede observar con los propios ojos" (1083-1084).

25. E. Poniatowska, Massacre in Mexico, trans. H. R. Lane, New York, Viking, 1975, p. 175: "Los ferrocarrileros en 1958 estuvieron solos. Nosotros no".

26. E. Poniatowska, Massacre in Mexico, p. 175. Interestingly enough, the official English translation here inverts the original quote's positive ("solo" to "no support") and negative inflections ("Nosotros no" to "the students did"), denuding the phrase's political bite and removing entirely Luis González de Alba's self-identification with the demonstrators. Although not one of the goals of this article, a comparative analysis of the various translations between the Spanish and the English and French versions of the reportage would prove extremely insightful.

27. B. Jörgensen, "Framing Questions", p. 82.

28. E. Poniatowska, Massacre in Mexico, p. 192.

29. Qtd. in L. González de Alba, Los días y los años, Mexico City, Ediciones Era, 1971, p. 201.

30. E. Poniatowska, Massacre in Mexico, p. 194.

31. Ibid., p. 198.

32. F. Léziart, p. 37 : “En outre, pour ancrer le récit dans la réalité, l'auteure mexicaine s'est longuement documentée et les photographies sont sélectionnées très scrupuleusement, tout comme les événements rapporté".

33. B. Chevigny, p. 58.

34. E. Poniatowska, Massacre in Mexico, p. 3. 
35. Ibid., p. 3.

36. H. Arendt, Eichmann in Jerusalem: A Report on the Banality of Evil [1963], New York, Penguin, 1994, p. 250.

37. O. Paz, "Introduction", in E. Poniatowska, Massacre in Mexico, p. VII.

38. E. Poniatowska, Massacre in Mexico, p. 1.

39. Ibid., p. 5.

40. Ibid., p. 11.

41. Ibid., p. 12.

42. Ibid., p. 52.

43. Ibid., p. 82.

44. C. Harris, "Remembering 1968 in Mexico: Elena Poniatowska's La noche de Tlatelolco as Documentary Narrative", Bulletin of Latin American Research, vol. 24, n 4, 2015, p. 484.

45. C.A. Vidal Claramonte, "Translating Oral Micro-histories Ethically: The Case of Elena Poniatowska", Translation \& Interpreting: The International Journals of Translation and Interpreting Research, vol. 11, $\mathrm{n}^{\circ}$ 2, 2019, p. 76.

46. Ibid., p. 81.

47. Ibid., p. 82.

48. D. Sorensen, p. 311.

49. C. Brewster, "Elena Poniatowska: Then, Now and Forever", Diálogo, vol. 17, n 1, 2014, p. 115.

50. Qtd. in T. Karam Cárdenas, “Acercamiento semiótico al estudio de la crónica testimonial en la obra de Elena Poniatowska", Espéculo: Revista de Estudios Literarios, $\mathrm{n}^{\circ} 33,2006$. Available at <https://webs.ucm.es/info/especulo/numero33/eleponia.html> [consulted 1 May 2020]: "Las frases sintetizan el proceso, las declaraciones iluminan el ánimo del movimiento. Al fragmentar y elegir los testimonios más directos, se esencializan las razones más profundas del 68 y la conversión del enfrentamiento político en descubrimiento existencial de los límites y los alcances del poder".

51. D.W. Foster, "Latin American Documentary Narrative", in Theoretical Debates within Spanish American Literature, eds. D.W. Foster and D. Altamiranda, New York and London, Garland, 1997, p. 53.

52. B. Jörgensen, "Framing Questions", p. 82.

53. J. Paddock, “Oscar Lewis's Mexico”, Anthropological Quarterly, vol. 34, n 3, July 1961, p. 146.

54. E. Poniatowska, Massacre in Mexico, p. 5-6.

55. Ibid., p. 20-22.

56. Ibid., p. 49-50.

57. Ibid., p. 84

58. Ibid., p. 91-92.

59. M. Bakhtin, Problems of Dostoevsky's Poetics, trans. C. Emerson, Minneapolis and London, University of Minnesota Press, 1984, p. 110.

60. E. Poniatowska, Massacre in Mexico, p. 14.

61. Ibid., p. 16, 17.

62. Ibid., p. 17.

63. Ibid., p. 17.

64. Ibid., p. 66.

65. Ibid., p. 104.

66. Ibid., p. 106-107.

67. Ibid., p. 110-111.

68. Ibid., p. 119.

69. Ibid., p. 166.

70. Ibid., p. 166: "Freedom is the subject / The verb is rifles / Death is the object".

71. Ibid., p. 169. 
72. In the English translation, the photo-essay appears right after Rosario Castellanos's poem, whereas in the original version it is placed at the very beginning of the book, followed immediately by Poniatowska's brief introduction.

73. As R. Bisson-Fradet notes, "This oxymoron between historical material and fiction creates tensions between the historical and literary discursive practices that coexist in the narrative, prompting an exploration of the narrative processes that Elena Poniatowska uses to make the chronicle and fiction coexist within the same text" "Cet oxymore entre matériel historique et fiction annonce les tensions entre les pratiques discursives historiques et littéraires coexistant dans le récit, qui nous ont conduite à une exploration des procédés narratifs dont Elena Poniatowska use pour faire coexister la chronique et la fiction") (4).

74. Poniatowska's introduction ends on this note: "In these pages there echo the cries of those who died and of those who lived on after them. These pages express their outrage and their protest: the mute cry that stuck in thousands of throats, the blind grief in thousands of horrorstricken eyes on October 2, 1968, the night at Tlatelolco".

E. Poniatowska, Massacre in Mexico, p. 199.

75. E. Poniatowska, Massacre in Mexico, p. 201.

76. Ibid., p. 223.

77. Ibid., p. 225.

78. Ibid., p. 235.

79. Ibid., p. 235.

80. Ibid., p. 238.

81. Ibid., p. 227.

82. Ibid., p. 263.

83. As R. Bisson-Fradet writes, "The peculiarity of the Mexican author lies in her work's hybridity that combines journalistic genres and literary techniques [...]. [T]he chronicle interferes in Elena Poniatowska's fictional works. The reader is thus led to reflect on the truth of the facts" ("La particularité de l'auteure mexicaine réside dans l'hybridité générique de ses ouvrages qui combinent les techniques journalistiques et littéraires, [...] nous avons remarqué que la chronique s'immisce dans les œuvres fictionnelles d'Elena Poniatowska. Le lecteur est donc amené à réfléchir sur la véracité des faits") (1-2).

84. Ibid., p. 307.

85. M. Schuessler, Elenísima. Ingenio y figura de Elena Poniatowska, Mexico City, Diana, 2003, p. 144.

86. Do sepow pojde tells the story of Jesusa Palancares, a poor women who fought in the Mexican Revolution and who later became a washerwoman in Mexico City. The book is considered a breakthrough in testimonial literature, written after about ten years of interviews with the real Jesusa Palancares (Josefina Bohorquez). In her testimonial novel, Poniatowska reworks transcriptions of hundreds of hours of conversations, creating a classic of Mexican literature. Although Here's to You, Jesusa was published in Poland, readers saw it as a natural continuation of the sociological work of Oscar Lewis rather than as a literary phenomenon in itself.

Two years before her experience with Bohorquez, in 1962, Poniatowska briefly assisted the American anthropologist Oscar Lewis, known as one of the founders of testimonial writing. Poniatowska helped Lewis edit one of his works dedicated to "culture of poverty", Pedro Martínez: A Mexican Peasant and His Family, translated into Polish in 1970. Lewis's particular method consisted of merging art and science by invoking literariness of personal narrative as a rhetorical strategy for combating the dryness of the scientific document. In order to achieve his goal, he would spend hundreds of hours with his informants in their homes, ate with them, joined their fiestas, listened to their conversations and discussed with them the history of their lives. His assistants used to accompany him during the interviews and edit the material later, eliminating repetitions and useless digressions. Poniatowska became familiar with his method and, as she has explained later, it would influence her writing in Here's to You, Jesusa. Lewis's book, The Children of 
Sánchez. Autobiography of a Mexican Family (1961), was published in Poland in 1964 and gained some popularity that increased years later when, in 1978, Hollywood turned it into a movie starring Anthony Quinn.

87. "La junte péruvienne dénonce l'accord pétrolier conclu avec une filiale de la Standard/ À Mexico, plusieurs délégations expriment leur inquiétude pour les Jeux", Le Monde, 7 Oct. 1968: "Worries continue in Mexico, a week before the inauguration of the Olympic Games, but calm returned to the capital following the shooting on the Place des Tres Cultures, which reportedly left more than thirty dead and a hundred seriously injured. It is estimated that fifteen hundred people, including the majority of the strike committee's leaders, were arrested. According to an informed source, it is said that Mexican authorities had decided to use force to disperse the meeting of student leaders on the Place de las Tres Culturas in order to break the university protests and arrest the student leaders" ("L'inquiétude persiste au Mexique, à une semaine de l'inauguration des Jeux olympiques. Mais le calme est revenu dans la capitale, après la fusillade de la place des Trois-Cultures, qui aurait fait plus de trente morts et une centaine de blessés graves. On estime que quinze cents personnes, dont la majorité des dirigeants du comité de grève, ont été arrêtées. De source bien informée, on affirme que les autorités mexicaines avaient décidé de disperser par la force la réunion des dirigeants étudiants sur la place des TroisCultures, afin de briser le mouvement de contestation universitaire et de s'emparer des dirigeants étudiants").

88. There were also News of a Kidnapping (from 1996), published in Poland in 1997 and Chronicle of a Death Foretold (from 1981) published in Poland in 1987.

\section{ABSTRACTS}

In France and Poland where journalisme littéraire and reportaż have enjoyed long and rich traditions, it is curious that Elena Poniatowska's literary journalism has attracted little attention. The reasons differ in degree, but translations efforts in both countries suggest that the French and the Poles see Poniatowska strictly as a Latin American Boom writer and, as such, favor her fiction over her socially-engaged literary journalism. By examining the international literary journalistic and reportage traditions inscribed within Poniatowska's most celebrated crónica, La noche de Tlatelolco, this article attempts to counter these current trends in France and in Poland. A daughter of France with royal Polish blood, Poniatowska might have focused her attention this past half century on the troubled history of her adopted nation, Mexico, and on its victimized and marginalized peoples, but her journalistic themes, oral histories, interviewing techniques and literary talents are as universal as those from any French or Polish grand reporter.

On peut s'étonner que les reportages (crónica) d'Elena Poniatowska aient attiré si peu d'attention en France et en Pologne, deux pays où le journalisme littéraire possède des traditions anciennes et variées. Les raisons de ce manque d'intérêt sont multiples mais, dans les deux cas, il semble que les Français et les Polonais considèrent Poniatowska avant tout comme un écrivain du Boom latino-américain et, par conséquent, favorisent son œuvre de fiction, ignorant sa pratique du journalisme littéraire, socialement engagée. Cet article se propose de mettre en évidence la richesse de la technique du reportage dans la plus célèbre crónica d'Elena Poniatowska, La Noche de Tlatelolco (1971), qui puise à différentes sources. Loin de concentrer son attention sur l'histoire troublée de sa nation d'adoption, le Mexique, cette journaliste d'origine franco-polonaise, par les 
thèmes qu'elle aborde et par les techniques qu'elle utilise, propose une œuvre aussi universelle que celle des grands reporters français ou polonais.

\section{INDEX}

Mots-clés: journalisme littéraire, reportage littéraire, cronicà, Elena Poniatowska

Keywords: literary journalism, literary reportage, cronicà, Elena Poniatowska

\section{AUTHORS}

\section{JOHN S. BAK}

John S. Bak is Professeur at the Université de Lorraine in France and founding President of the IALJS. He holds degrees from the universities of Illinois, Ball State and the Sorbonne. In addition to articles on literary journalism, he co-edited (with Bill Reynolds) Literary Journalism across the Globe (2011) and The Routledge Companion to Global Literary Journalism (forthcoming, 2023). He heads the research project ReportAGES on literary journalism and war and was recently awarded a three-year research grant to study the influences of the French press on the Chilean crónica.

\section{ALEKSANDRA WIKTOROWSKA}

Aleksandra Wiktorowska received her $\mathrm{PhD}$ in Construction and Representation of Cultural Identities from the Universität de Barcelona in 2014. In addition to being an academic scholar and a journalist she is a translator from Spanish to Polish with nine novels to her credit. 